\title{
Influence of Silicon and Chlorothalonil on the Suppression of Gray Leaf Spot and Increase Plant Growth in St. Augustinegrass
}

\author{
M. O. Brecht, Graduate Research Assistant, University of Florida-IFAS, Department of Plant Pathology, Gainesville \\ 32607; L. E. Datnoff, Professor of Plant Pathology, University of Florida-IFAS, Department of Plant Pathology, Ev- \\ erglades Research and Education Center, Belle Glade 33430; T. A. Kucharek, Professor of Plant Pathology, Univer- \\ sity of Florida-IFAS, Department of Plant Pathology, Gainesville; and R. T. Nagata, Associate Professor of Plant \\ Breeding, University of Florida-IFAS, Department of Horticulture, Everglades Research and Education Center, Belle \\ Glade
}

\begin{abstract}
Brecht, M. O., Datnoff, L. E., Kucharek, T. A., and Nagata, R. T. 2004. Influence of silicon and chlorothalonil on the suppression of gray leaf spot and increase plant growth in St. Augustinegrass. Plant Dis. 88:338-344.

Silicon, applied as calcium silicate slag $(20 \% \mathrm{Si})$, was evaluated for its potential to suppress gray leaf spot (Magnaporthe grisea) and increase plant growth in newly planted St. Augustinegrass in the summers of 2000 and 2001. Calcium silicate was applied $(1,000 \mathrm{~kg} \mathrm{Si} / \mathrm{ha})$ to three sites that contained Si-deficient Histosols prior to sprigging St. Augustinegrass, cv. Floratam, in southern Florida. This treatment was compared with foliar sprays of chlorothalonil, calcium silicate plus chlorothalonil, and an untreated control. Immediately after planting, applications of chlorothalonil ( $720 \mathrm{~g} / \mathrm{liter})$ were made every 10 days for a total of seven sprays at a rate of 7.6 $\mathrm{kg}$ a.i./ha with a commercial sprayer. Based on area under the disease progress curve (AUDPC) values for the treatments calcium silicate alone, chlorothalonil, and calcium silicate plus chlorothalonil, gray leaf spot was reduced by 7,65 , and $68 \%$ at site one, 28,34 , and $59 \%$ at site two, and 41,55 , and $68 \%$ at site three, respectively when compared with the untreated control The application of calcium silicate alone significantly reduced the final AUDPC of gray leaf spot when compared with the control at site two only. However, when disease severities were analyzed by week, the calcium silicate treatment significantly reduced the percentage of disease at weeks 2,6 , and 8 at site one and weeks 3 to 8 at site three when compared with the control. The final percent bare ground coverage for St. Augustinegrass was increased significantly using calcium silicate by 17 and $34 \%$ over the control at sites one and two, respectively $(P \leq 0.05)$. Silicon was the only element to significantly increase in the leaf tissue for treatments amended with calcium silicate. Levels of $\mathrm{Si}$ in leaves for treatments amended with calcium silicate were from 1.2 to $1.3 \%$, while those not receiving calcium silicate had only 0.6 to $0.7 \%$. Amendments with calcium silicate slag for St. Augustinegrass sod production on Si-deficient soils may be an option to reduce gray leaf spot development in newly sprigged fields and promote earlier ground coverage of grass when the environment is favorable for disease.
\end{abstract}

Additional keywords: Stenotaphrum secundatum

St. Augustinegrass (Stenotaphrum secundatum (Walter) Kuntze.) is a coursetextured, warm-season lawn grass which is grown extensively from southern California to the Gulf Coast states (11). In Florida, it is estimated that $72 \%$ of the total sod

Corresponding author: L. E. Datnoff

E-mail: leda@mail.ifas.ufl.edu

This research was supported in part by the Florida Agricultural Experiment Station, and approved for publication as Journal Series No. R-09443.

This work was funded by Calcium Silicate Corporation, Inc., Florida Turfgrass Association, Syngenta, Turf Producers International, and University of Florida-IFAS.

Accepted for publication 30 October 2003.

Publication no. D-2004-0126-01R

(C) 2004 The American Phytopathological Society production (21,220 ha) is St. Augustinegrass (13). Interestingly, the cv. Floratam makes up $80 \%$ of the total St. Augustinegrass grown. Growers produce highquality sod that is used to establish lawns for residential, business, and recreational facilities alike.

In Florida, gray leaf spot, caused by the fungus Magnaporthe grisea (T. T. Hebert) Barr (anamorph Pyricularia grisea (Cooke) Sacc.), is a common disease in St. Augustinegrass. Warm temperatures and wet weather are favorable environmental conditions for development of gray leaf spot. Symptoms of gray leaf spot initially appear as small, brown to red lesions in leaves and stolons. These lesions quickly enlarge into round to oblong spots with necrotic centers, which are gray to tan with brown to red borders within a halo or general chlorosis on the outer most peripheries (17). The disease can cause leaves and stolons to die and make entire plantings appear scorched $(2,10,17,23)$. During the extended summer months in Florida, damage seems to be most severe in newly planted sod plugs and regenerating sod fields $(2,10)$. Freeman (10) reported that gray leaf spot reduced the ground coverage of newly sprigged St. Augustinegrass by an average of $36 \%$. Consequently, gray leaf spot can be a troublesome problem for the sod producer and home consumer.

Currently, gray leaf spot may be managed by the use of partially resistant cultivars or spraying with a fungicide such as chlorothalonil $(2,4)$. With increasing concerns about pesticides, alternative methods to control diseases are needed. Recent research has demonstrated that silicon $(\mathrm{Si})$ can control diseases in a number of hosts as well as provide other agricultural benefits (7).

Although $\mathrm{Si}$ is the second-mostabundant element in the earth's soil and is a component of plants, it is not considered to be an essential element as defined by Arnon and Stout (1), except for members of the family Equisitaceae (9). However, when silicon is amended to soils or nutrient solutions low in soluble $\mathrm{Si}$, plants exhibit improved growth and yield, better disease and insect resistance, and reduced mineral toxicities $(3,9,18-21)$. Currently, crops such as rice and sugarcane, which accumulate high levels of $\mathrm{Si}$ in the plant tissue, are fertilized routinely with calcium silicate slag to produce higher yields $(20,21)$. In Florida, fertilization with calcium silicate in rice is a routine practice for disease management of blast ( $M$. grisea), brown spot (Cochliobolus miyabeanus (Ito \& Kuribayashi in Ito) Drechs. ex Dastur), and sheath blight (Thanatephorus cucumeris (A.B. Frank) Donk). Preliminary research for rice in Florida first suggested that $\mathrm{Si}$ needs to be applied if extractable $\mathrm{Si}$ is $10 \mathrm{mg} \mathrm{liter}^{-1}$ or less in soil (24). When 0.5 M HOAc-extractable $\mathrm{Si}$ is near $25 \mathrm{mg} \mathrm{liter}^{-1}$ in soil, then the rice straw Si content will be $3 \%$ or greater and $\mathrm{Si}$ applications are not needed. More recently, a calculated critical level for $\mathrm{Si}$ in the soil (point below which response to $\mathrm{Si}$ fertilizer is expected) was estimated at 19 mg liter ${ }^{-1}$ (15). 
Silicon also has been shown to have positive effects in various turfgrasses. Saigusa et al. (19) demonstrated that silicon amendments to zoysia grass $\mathrm{cv}$. Miyako (Zoysia japonica Steud.) improved the resistance to wear, insect feeding by $R u$ sidra depravata, and disease resistance to Rhizoctonia solani. Growth and establishment of creeping bentgrass (Agrostis palustris Huds.) was increased with fertilization with silicon, while disease severity of Pythium aphanidermatum was highest in treatments containing the highest rate of $\mathrm{Si}$ (12). Recently, Datnoff and Nagata (6) showed in the greenhouse that an amendment of calcium silicate slag to a soil that was low in soluble Si reduced gray leaf spot disease 19 to $78 \%$ among several cultivars of St. Augustinegrass. This study also indicated that levels of $\mathrm{Si}$ in St. Augustinegrass were increased more than twofold compared with the control for all the cultivars tested. Silicon seems to increase the resistance to gray leaf spot; therefore, field studies were initiated to further investigate these effects in newly planted St. Augustinegrass. The objective of this study was to evaluate the effect of calcium silicate on the suppression of gray leaf spot and ground coverage of St. Augustinegrass when compared with or in combination with a fungicide (chlorothalonil) in a commercial sod-production setting.

\section{MATERIALS AND METHODS}

Field experiments were conducted in the summer of 2000 at two locations and the summer of 2001 at one location on Sideficient Histosols located in the Everglades Agricultural Area in south Florida. Site one was located at King Ranch, a sod and sugarcane producer, approximately 15 $\mathrm{km}$ south of South Bay, FL. Using the soil test developed by Snyder (24), soils at this field site had $0.5 \mathrm{M} \mathrm{HOAc-extractable} \mathrm{Si}$ at $14 \mathrm{mg} /$ liter (below the $19 \mathrm{mg} /$ liter critical level for $\mathrm{Si}$ in rice production) 2

Table 1. Chemical analysis of calcium silicate slag

\begin{tabular}{lc}
\hline Ingredient & $\begin{array}{c}\text { Analysis } \\
(\mathbf{\%})\end{array}$ \\
\hline Total phosphoric acid $\left(\mathrm{P}_{2} \mathrm{O}_{5}\right)$ & 2.75 \\
Insoluble phosphoric acid $\left(\mathrm{P}_{2} \mathrm{O}_{5}\right)$ & 2.75 \\
Available $\mathrm{P}_{2} \mathrm{O}_{5}$ & 0.00 \\
Water-soluble $\mathrm{K}_{2} \mathrm{O}$ & 0.80 \\
Aluminum $(\mathrm{Al})$ & 2.24 \\
Boron $(\mathrm{B})$ & 0.01 \\
Calcium $(\mathrm{Ca})$ & 29.6 \\
Copper $(\mathrm{Cu})$ & 0.003 \\
Iron $(\mathrm{Fe})$ & 0.20 \\
Total magnesium $(\mathrm{Mg})$ & 0.18 \\
Manganese $(\mathrm{Mn})$ & 0.06 \\
Total sulfur $(\mathrm{S})$ & 0.28 \\
Zinc $(\mathrm{Zn})$ & 0.003 \\
Cobalt $(\mathrm{Co})$ & 0.001 \\
Molybdenum $(\mathrm{Mo})$ & $<0.005$ \\
Silicon dioxide $\left(\mathrm{SiO}_{2}\right)^{\mathrm{z}}$ & 43.41 \\
\hline z Silicon $=20 \%$. &
\end{tabular}

months before planting (15). The second and third field sites were located at Woerner Turf Farm, a sod and sugarcane farm, located $30 \mathrm{~km}$ south of South Bay. The Woerner Turf Farm sites two and three had a soil containing $0.5 \mathrm{M}$ HOAc-extractable $\mathrm{Si}$ at 10 and $4 \mathrm{mg} / \mathrm{liter}$, respectively. All field sites had an average soil $\mathrm{pH}$ level of 6.3 .

Prior to planting, the soil was tilled and laser leveled to ensure uniform soil drainage and a flat, level surface for planting and harvesting. For weed management, the fields were left fallow for 2 weeks to allow any weeds present to germinate. Weeds then were sprayed with the nonselective herbicide glyphosate (Round-Up; Monsanto Company, St. Louis) and the soil was disked 3 days later. Calcium silicate slag $\left(\mathrm{CaSiO}_{3}\right)$ (Calcium Silicate Corporation, Inc., Lake Harbor, FL; Table 1) was applied in a broadcast manner and soilincorporated at rates of 0 and 5 metric tons $(\mathrm{mt}) / \mathrm{ha}$ (elemental Si at $1 \mathrm{mt} / \mathrm{ha})$. The 5t/ha rate was chosen because it is the rate commonly used for rice production in Florida, and confers good disease resistance and yield per dollar spent (5). St. Augustinegrass was established by planting $10-\mathrm{cm}^{2}$ sod plugs of the gray leaf spotsusceptible cv. Floratam in rows on $30-\mathrm{cm}$ centers. Fields then were rolled to press the plugs firmly into the soil and watered to maintain optimal soil moisture for establishment. Experiments were fertilized at planting with a 10-10-10 (N-P-K) granular fertilizer at a rate of $337 \mathrm{~kg} / \mathrm{ha}$. Both sites were prepared and maintained by the growers according to current sodproduction practices. The plugs were planted on 19 April 2000 at site one, 6 June 2000 at site two, and 30 August 2001 at site three.

The experimental designs at all three locations were randomized complete blocks with four treatments, each having four replications. The size of each experimental unit was 15.3 by $123 \mathrm{~m}$. The treatments included an untreated control (no calcium silicate and no chlorothalonil), calcium silicate alone, chlorothalonil alone, and calcium silicate plus chlorothalonil. Applications of chlorothalonil (Daconil Weather Stik; Syngenta Int. AG, Basel, CH) were sprayed at a rate of $7.6 \mathrm{~kg}$. a.i./ha in a spray volume of 150 liters/ha immediately after planting and continued every 10 days until the end of the experiment (11 to 12 weeks). The label rate for the fungicide to control gray leaf spot on St. Augustinegrass is 4.6 to $8.2 \mathrm{~kg}$. a.i./ha every 7 to 14 days. Both calcium silicate and chlorothalonil were applied to the center $9.2 \mathrm{~m}$ of each experimental unit to reduce any interplot drift.

Five plugs of Floratam per experimental unit were tagged and evaluated for gray leaf spot development throughout the course of the experiment. Plugs were selected every $20 \mathrm{~m}$ down the middle of each experimental unit. Selected plugs were made distinct by removing surrounding plugs in a $1.5-\mathrm{m}$ radius. Severity of gray leaf spot of tagged plugs was recorded weekly as a visual rating of percent leaf area diseased. Ratings were recorded at 1week intervals starting 3 weeks after planting, unless otherwise noted. Data are based on eight evaluations from 10 May through 29 June 2000 at site one, nine evaluations from 28 June through 23 August 2000 at site two, and eight evaluations from 20 September through 8 November 2001 at site three.

Disease ratings were used to create disease progress curves for each treatment. Treatment effectiveness was determined by calculating individual area under the disease progress curves (AUDPCs), with the formula:

$$
\mathrm{AUDPC}=\sum_{i=1}^{n}\left[\left(y_{i}+y_{i+1}\right) / 2\right]\left(t_{i+1}-t_{i}\right)
$$

where $y_{i}=$ disease proportion at the $i$ th observation, $t_{i}=$ time (in days), and $n=$ total number of evaluations (22).

A separate percent bare ground coverage rating down the middle of each experimental unit, away from the individually tagged plugs, was recorded at the end of the experiment (11 to 12 weeks after planting). Six ratings were recorded every $15 \mathrm{~m}$ per experimental unit by estimating a visual percent area of bare ground covered by grass in a $2-\mathrm{m}^{2}$ area.

Approximately $10 \mathrm{~g}$ of leaf tissue from each experimental unit were obtained 3, 7, and 11 weeks after planting of grasses from the field experiments to determine nutrient levels. Leaves removed were selected randomly down the middle of each experimental unit. Leaves then were

Table 2. Average temperatures, total rainfall, and average maximum humidities during the months experiments were conducted for sites one, two, and three in south Florida

\begin{tabular}{lccc}
\hline Site, month, year & Temperature $\left(\mathbf{C}^{\circ}\right)$ & Rainfall $(\mathbf{c m})$ & Maximum humidity $(\%)$ \\
\hline 1, April 2000 & 21.3 & 9.1 & 98 \\
1, May 2000 & 24.4 & 6.3 & 99 \\
1, June 2000 & 25.7 & 13.5 & 100 \\
2, July 2000 & 26.1 & 25.1 & 100 \\
2, August 2000 & 26.0 & 9.1 & 100 \\
2, September 2000 & 26.0 & 17.8 & 100 \\
3, August 2001 & 26.7 & 22.1 & 100 \\
3, September 2001 & 24.9 & 35.5 & 100 \\
3, October 2001 & 23.3 & 9.0 & 99 \\
\hline
\end{tabular}



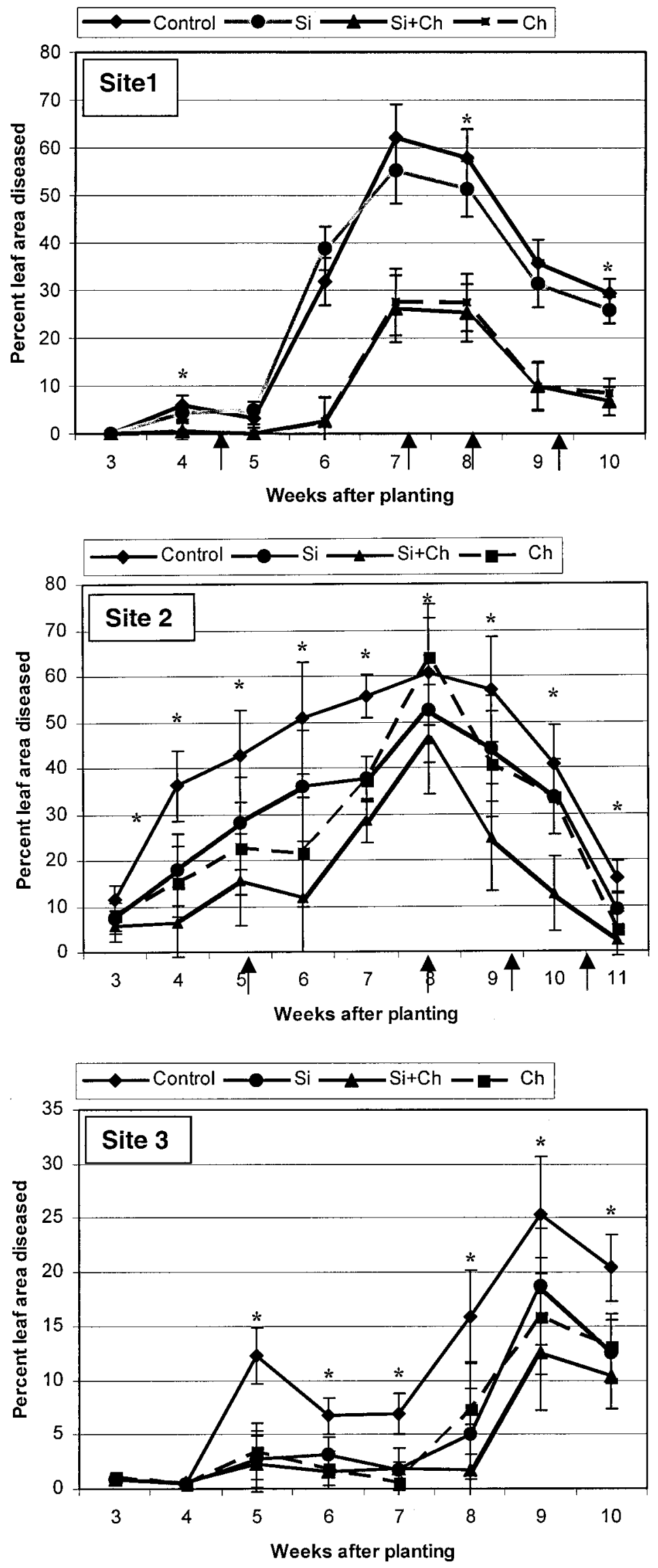

Fig. 1. Disease progression of gray leaf spot in St. Augustinegrass treated with calcium silicate (Si), chlorothalonil $(\mathrm{Ch})$, calcium silicate plus chlorothalonil $(\mathrm{Si}+\mathrm{Ch})$, or untreated control at sites one, two, and three with least significant bars. Arrows $(\uparrow)$ indicate when experiments were mowed. Asterisks $(*)$ designate when the calcium silicate slag treatments significantly lowered gray leaf spot disease severity compared with the control $(P \leq 0.05)$. washed, dried, and ground in a Wiley mill (Thomas Scientific, Swedesboro, NJ) to pass through a 40-mesh screen. Levels of calcium $(\mathrm{Ca})$, copper $(\mathrm{Cu})$, iron $(\mathrm{Fe})$, potassium $(\mathrm{K})$, magnesium $(\mathrm{Mg})$, manganese $(\mathrm{Mn})$, nitrogen $(\mathrm{N})$, phosphorous $(\mathrm{P})$, and zinc $(\mathrm{Zn})$ were obtained from these leaf samples by using Wolf's digestion method (27). Silicon was obtained from leaf samples as described by Elliot and Snyder (8) with subsequent automated colorimetric analysis to obtain milligram-per-liter values. Soil samples, collected at a depth of $10 \mathrm{~cm}$, were obtained from the middle of each experimental unit at the beginning ( 3 weeks after planting), at the middle ( 7 weeks after planting), and at the end (11 weeks after planting) of the experiments in order to determine soil $\mathrm{pH}$ and levels of $\mathrm{Ca}$ and $\mathrm{Si}$. Levels of $\mathrm{Ca}$ and $\mathrm{Si}$ were determined using the acetic acid extraction method, which was performed at the University of Florida, Belle Glade EREC soil testing facility.

Statistical analyses were performed using the analysis of variance (ANOVA) procedure in the SAS statistical analysis software (Windows version 8.02; SAS Institute, Cary, NC). Treatment means for AUDPC and percent bare ground coverage were separated using Fisher's Protected least significant difference test, while the percent mineral content in leaf tissue means were separated using the Student's $t$ test. Significance was determined at $P \leq 0.05$.

\section{RESULTS}

Environment. For the first three ratings at site one, the environmental conditions were dry and thus not conducive for gray leaf spot development. Environmental conditions did not become conducive for good disease development until after the third rating at site one, when frequent summer rains started to develop. Environmental conditions then allowed for moderate to high levels of disease for the rest of the experiment. At site two, the environmental conditions were conducive for a sustained moderate to high level of disease throughout the experiment. Site three was planted late in the summer and environmental conditions allowed for low to moderate disease pressure. Average temperatures, total rainfall, and average maximum humidities are presented in Table 2. The extended warm, sunny conditions during the summer and early fall provide optimal conditions for growth of stolons and leaves.

Gray leaf spot. The progression of disease severity over 8 weeks at sites one and 3 and 9 weeks at site 2 are presented in Figure 1. The calcium silicate treatment significantly lowered the gray leaf spot severity when compared with the control at weeks 4,8 , and 10 at site one, weeks 3 through 11 at site two, and weeks 5 through 10 at site three $(P \leq 0.05$; Fig. 1$)$. The treatments of chlorothalonil and the 
combination of chlorothalonil and calcium silicate generally lowered the gray leaf spot severity significantly when compared with the control at all three sites $(P \leq 0.05$; Fig. 1).

The calcium silicate treatment had significantly lower (28\%) final AUDPC of percent gray leaf spot at site two, but not at sites one and three when compared with the control ( $P \leq 0.05$; Fig. 2). Calcium silicate alone was as effective as the chlorothalonil fungicide treatment at site two only (Fig. 2). Chlorothalonil significantly decreased the final AUDPC (34 to $65 \%)$ at sites one and two only, when compared with the control $(P \leq 0.05$; Fig. $2)$. The chlorothalonil treatment was significantly better than the calcium silicate treatment in suppressing the final AUDPC at site one only, but was not significantly better than the calcium silicate treatment at either sites two or three ( $P \leq 0.05$; Fig. 2$)$. The combination of calcium silicate plus chlorothalonil was significantly different from the chlorothalonil treatment at site two but not at sites one and three. At site two, the combination treatment had a significantly lower AUDPC than the chlorothalonil or calcium silicate treatments alone (37 and $43 \%$, respectively; $P$ $\leq 0.05$; Fig. 2).

Bare ground coverage. Final percent bare ground coverage for St. Augustinegrass in the calcium silicate treatment was significantly increased by 17 and $34 \%$ over the controls at sites one and two, respectively $(P \leq 0.05$; Fig. 3$)$. Data are not available for site three. The chlorothalonil treatment was significantly better (52\%) than the calcium silicate treatment at site two only ( $P \leq 0.05$; Fig. 3 ). The combination of calcium silicate plus chlorothalonil treatment significantly increased the bare ground coverage (57\%) compared with the control at site two only ( $P \leq 0.05$; Fig. 3$)$.

Soil nutrient levels. Soils from sites one and two were analyzed at 3, 7, and 11 weeks after planting in order to determine the effects of calcium silicate slag on the levels of $\mathrm{Si}, \mathrm{Ca}$, and $\mathrm{pH}$. Levels of $\mathrm{Si}$ in the soils amended with slag had a mean level of $125.6 \mathrm{mg} / \mathrm{liter}$ over the 11 weeks and were significantly higher than those treatments not receiving calcium silicate, which had a mean Si level of $14.2 \mathrm{mg} /$ liter $(P \leq$ 0.05; Table 3). Treatments amended with calcium silicate had a mean $\mathrm{Ca}$ level of $1,803 \mathrm{mg} / \mathrm{liter}$, while treatments not receiving calcium silicate had a mean Ca level of 1,668 mg/liter (Table 3). Treatments amended with calcium silicate were only significantly higher in $\mathrm{Ca}$ than those treatments not receiving slag at week $11(P \leq$ 0.05; Table 3). Treatments amended with calcium silicate had a mean soil $\mathrm{pH}$ of 6.4 and were not significantly different from treatments without calcium silicate, which had a mean pH of $6.3(P>0.05$; Table 3$)$.

Leaf tissue nutrients. Leaf tissue from sites one and two were analyzed at 3,7 , and 11 weeks after planting in order to determine the effects of calcium silicate on plant nutrient accumulation for $\mathrm{Ca}, \mathrm{Cu}, \mathrm{Fe}$, $\mathrm{K}, \mathrm{Mg}, \mathrm{Mn}, \mathrm{N}, \mathrm{P}$, and $\mathrm{Zn}$. At 3 weeks after planting, $\mathrm{Mg}$ was the only element significantly lower in treatments with calcium silicate than without $(P \leq 0.05$; data not shown). At 7 weeks after planting, levels of $\mathrm{Ca}$ and $\mathrm{Mg}$ in the leaf tissue were significantly lower in treatments with calcium silicate than without $(P \leq 0.05$; data not shown). At the end of the experiments (11
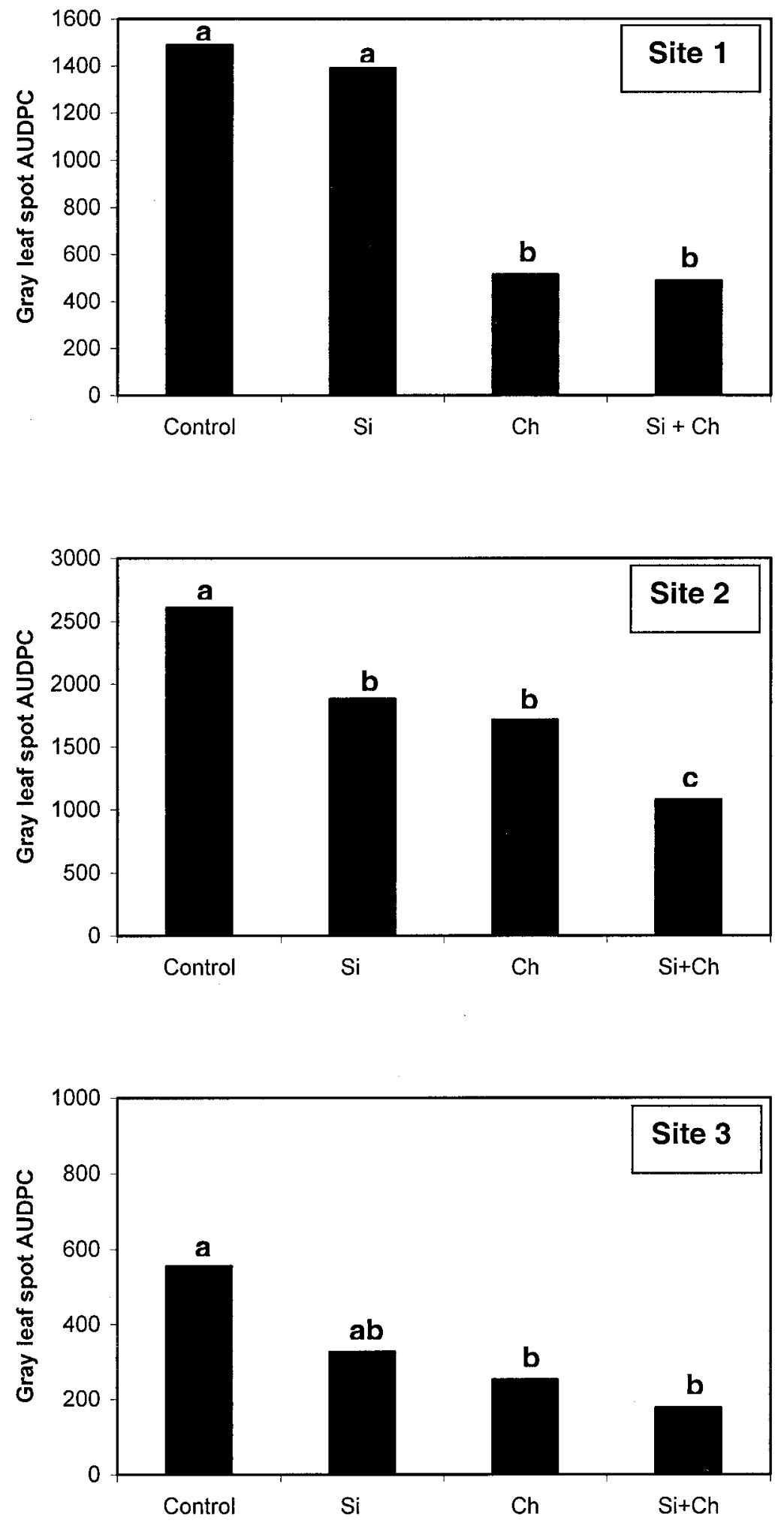

Fig. 2. Values of area under the disease progress curve (AUDPC) for gray leaf spot in St. Augustinegrass treated with calcium silicate $(\mathrm{Si})$ and chlorothalonil $(\mathrm{Ch})$, calcium silicate plus chlorothalonil $(\mathrm{Si}$ $+\mathrm{Ch}$ ), or untreated control at sites one, two, and three. Bars with the same letter do not differ significantly at $P \leq 0.05$ as determined by Fisher's protected least significant difference test. 
weeks after planting), leaf tissue levels of cantly lower in treatments with calcium silicate than without $(P \leq 0.05$; Fig. 4$)$. Si was the only element at 3,7 , and 11 weeks after planting to increase significantly in the leaf tissue in treatments amended with calcium silicate ( $P \leq 0.05$; Fig. 4$)$.

\section{DISCUSSION}

Unlike sites one and three, disease severity at site two was consistently moderate to high throughout the experiment. As a result, the AUDPCs for gray leaf spot severities were 43 and $79 \%$ greater in the untreated controls at site two compared with sites one and three. Differences in gray leaf spot AUDPCs among the three sites likely are due to the differences in planting date and subsequent levels of initial inoculum.

Gray leaf spot is a polycyclic disease; therefore, the disease progress curves at sites one, two, and three resemble that of a typical polycyclic curve as described by Van der Plank (25) until 7, 8, and 9 weeks after planting, respectively. The decline in severity of disease for all treatments at sites one, two, and three after the seventh, eighth, and ninth week after planting, respectively, may be explained by two fac$\mathrm{Ca}, \mathrm{Mg}, \mathrm{K}, \mathrm{P}, \mathrm{Zn}$, and $\mathrm{Cu}$ were signifi-

tors. First, resistance to $M$. grisea in rice is known to increase as leaf age of the plant increases (22). It is possible that resistance in St. Augustinegrass to $M$. grisea also may be the result of plant maturity; there has been good anecdotal evidence supporting this theory. Second, in sod production, grass is mowed frequently to encourage lateral growth. Mowing removes diseased and healthy tissue and contributes to inoculum dispersal. The decreases in disease toward the end of the study and following some of the mowing events most likely is due to the combination of removal of both diseased and healthy leaf tissue by the mower (25), as well as dilution of disease by growth of new, healthy leaf tissue.

The average levels of $\mathrm{Si}$ in the soil were significantly greater with the use of calcium silicate than without. Average levels of $\mathrm{Si}$ in the soil solution decreased slightly at each subsequent sampling, starting from $16 \mathrm{mg} / \mathrm{liter}$ ( 3 weeks after planting) to a final of $12 \mathrm{mg} /$ liter for treatments not receiving calcium silicate. Soil levels of $\mathrm{Si}$ for treatments with calcium silicate started off at an average of $178 \mathrm{mg} / \mathrm{liter}$ and decreased to a lower soil level of $107 \mathrm{mg} / \mathrm{liter}$ by the end of the experiment.

Average levels of $\mathrm{Ca}$ in soil generally were higher (6 to 9\%) for treatments

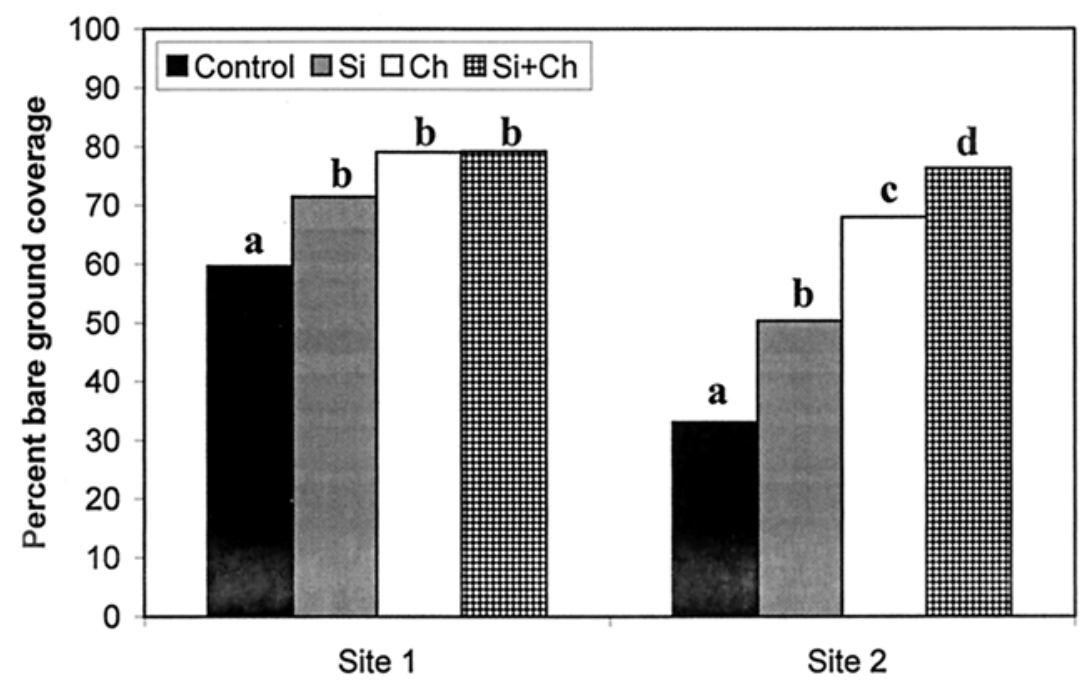

Field location

Fig. 3. Percent bare ground coverage in St. Augustinegrass treated with calcium silicate (Si), chlorothalonil $(\mathrm{Ch})$, calcium silicate plus chlorothalonil $(\mathrm{Si}+\mathrm{Ch})$, or untreated control at sites one and two. Bars with the same letter within the same field site do not differ significantly at $P \leq 0.05$ as determined by Fisher's protected least significant difference test.

Table 3. Combined soil concentrations at sites one and two of $\mathrm{Si}, \mathrm{Ca}$, and $\mathrm{pH}$ in treatments with (+) and without (-) calcium silicate slag at 3,7 , and 11 weeks after St. Augustinegrass planting ${ }^{z}$

\begin{tabular}{|c|c|c|c|c|c|c|}
\hline \multirow[b]{2}{*}{ Week } & \multicolumn{2}{|c|}{$\mathbf{S i}$ (mg/liter) } & \multicolumn{2}{|c|}{ Ca (mg/liter) } & \multicolumn{2}{|c|}{$\mathbf{p H}$} \\
\hline & + & - & + & - & + & - \\
\hline 3 & $177.9 \mathrm{a}$ & $16.3 \mathrm{~b}$ & $1,794.8 \mathrm{a}$ & $1,692.0 \mathrm{a}$ & $6.3 \mathrm{a}$ & $6.3 \mathrm{a}$ \\
\hline 7 & $92.0 \mathrm{a}$ & $13.8 \mathrm{~b}$ & $1,829.9 \mathrm{a}$ & $1,658.8 \mathrm{a}$ & $6.4 \mathrm{a}$ & $6.2 \mathrm{a}$ \\
\hline 11 & $106.8 \mathrm{a}$ & $12.5 \mathrm{~b}$ & $1,785.3 \mathrm{a}$ & $1,654.2 \mathrm{~b}$ & $6.4 \mathrm{a}$ & $6.3 \mathrm{a}$ \\
\hline
\end{tabular}

${ }^{\mathrm{z}}$ Treatment values with the same letter within a column do not differ significantly at $P \leq 0.05$ as determined by the Student's $t$ test. amended with calcium silicate throughout the experiments than for those without. However, only at the end of the experiment was the soil level of $\mathrm{Ca}$ significantly greater in plots with calcium silicate than in those without.

In general, treatments with calcium silicate had a slightly higher soil $\mathrm{pH}$ level than those without calcium silicate. However, there were no significant differences in levels of $\mathrm{pH}$ between the treatments at any of the sampling times. Calcium silicate at $5 \mathrm{t} / \mathrm{ha}$ does not seem to alter the $\mathrm{pH}$ of such calcareous Histosols.

In the plant tissue, silicon was the only element to increase consistently for treatments amended with calcium silicate, and had the highest order of magnitude change (50 to $54 \%)$. For treatments amended with slag, levels of Si in leaves were from 1.2 to $1.3 \%$, while those not receiving calcium silicate had only 0.6 to $0.7 \%$. In the calcium silicate treatments, the decreased disease levels and increased ground coverage ratings at the three sites are attributed to the increased levels of $\mathrm{Si}$ in the leaf tissue. Plant tissue values for $\mathrm{Ca}, \mathrm{Cu}, \mathrm{K}$, $\mathrm{Mg}, \mathrm{P}$, and $\mathrm{Zn}$ were significantly lower with calcium silicate than without at 11 weeks after planting. Ma and Takahashi (16) reported that decreased $\mathrm{Ca}$ in shoot tissues of rice plants might be the result of $\mathrm{Si}$ depressing the absorption of $\mathrm{Ca}$. It is thought that $\mathrm{Si}$ as silicic acid in the plant may compete with $\mathrm{Ca}$ for binding sites because silicic acid forms complexes with other organic acids, lignin, polyhydric alcohols, and phenol-carbohydrate compounds (14). This same phenomenon could be occurring with the other elements $(\mathrm{Cu}$, $\mathrm{K}, \mathrm{Mg}, \mathrm{P}$, and $\mathrm{Zn}$ ), too.

Calcium silicate significantly lowered the final AUDPC values compared with the control at site two only. Disease severities also were significantly lower in the treatments receiving calcium silicate compared with the untreated control for all rating dates at site two. Although the final AUDPC for the calcium silicate treatment was not significantly lower than the control at site one, disease severities at 4,8 , and 10 weeks after planting were reduced significantly. At site three, several of the treatment replications were not used in the final statistical analysis due to improper chlorothalonil applications. The reduction in statistical data points and high variation resulted in a high least significant difference value between treatments. Therefore, the final AUDPC for the calcium silicate treatment was not significantly different from the control at site three. However, gray leaf spot severity was significantly lower in the treatments with calcium silicate compared with the control at weeks 5 to 10 after planting. The chlorothalonil treatment significantly reduced AUDPCs at sites one, two, and three compared with the control; however, it seemed to lose efficacy at high levels of disease pressure. 
Chlorothalonil has been reported to be most effective when disease pressure is low to moderate (26). The combination of calcium silicate and chlorothalonil significantly reduced the AUDPC compared with

Gray leaf spot first was reported by Freeman (10) to reduce the ground coverage of newly planted plugs of St. Augustinegrass by an average of $36 \%$. Treatments with calcium silicate had significantly greater ground coverage when compared two. The percent bare ground coverage rating system estimates the effect of the treatments on growth of a number of St. Augustinegrass plugs at one time. Increased growth responses by the chlorothalonil treatments compared with the untreated control are a reflection of reduced disease severity. However, at this time, it is unclear whether the increased percent bare ground coverage of the calcium silicate and the combination treatments is a result of decreased disease, a physiological either treatment alone at only one site. with the untreated control at sites one and

growth response to the increased uptake of $\mathrm{Si}$, or both.

Fungicide treatments typically are not used at sod farms during establishment of newly planted fields or on regenerating ribbons $(3-\mathrm{cm}$ strip layer of grass composed of intact plants and stolons) left after a recent field harvest because of the costs and labor involved to maintain such a spray program (personal communication with farm managers at King Ranch and the Woerner Turf Farm). Sod producers, however, will use fungicides for spot treatment in the field during production and just before harvest, especially if gray leaf spot is active. Symptoms of gray leaf spot will lower sod grade quality; consequently lowering the price per pallet. As awareness of the potential impact of gray leaf spot on sod growth and development becomes more apparent to the sod producer, other control measures that would be long lasting and cost effective could be of interest. For example, a one-time soil incorporation of calcium silicate slag was equal to seven
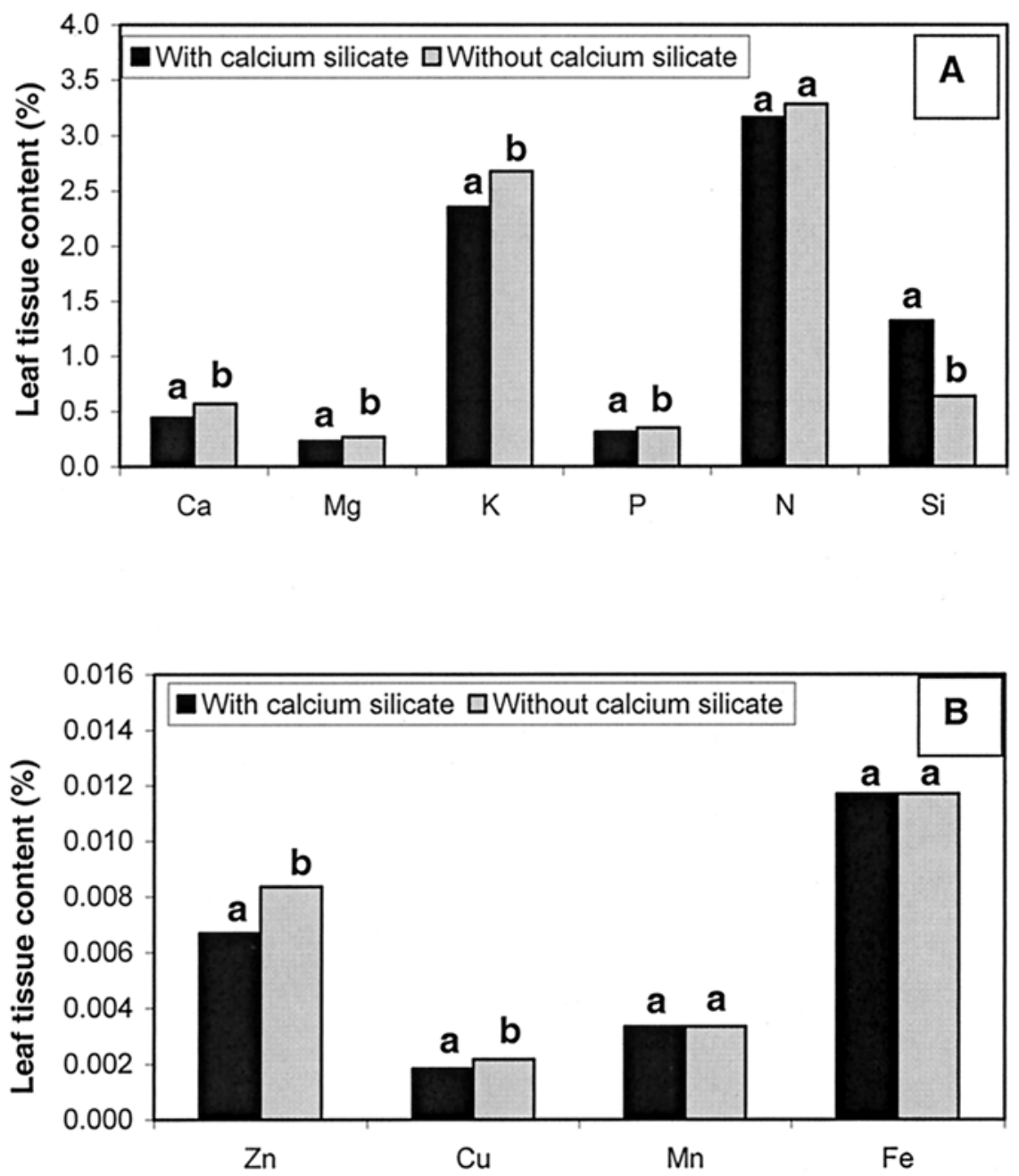

Fig. 4. Percent mineral content in leaf tissue with and without calcium silicate at the end (11 weeks after planting) of the experiments of $\mathbf{A}$, the major nutrients calcium $(\mathrm{Ca})$, magnesium $(\mathrm{Mg})$, potassium $(\mathrm{K})$, phosphorous $(\mathrm{P})$, nitrogen $(\mathrm{N})$, and silicon $(\mathrm{Si})$ and $\mathbf{B}$, the minor nutrients zinc $(\mathrm{Zn})$, copper $(\mathrm{Cu})$, manganese $(\mathrm{Mn})$, and iron $(\mathrm{Fe})$. These data reflect the combination of data from field sites one and two. Bars with the same letter do not differ significantly at $P \leq 0.05$ as determined by the Student $t$ test. applications of a fungicide over a 3-month period for suppressing gray leaf spot development at sites two and three. The combination of calcium silicate and chlorothalonil was significantly more effective at reducing disease severity only at site 2 . This suggests that fungicides might be better managed with Si. The number of applications or rates of applications might be reduced or eliminated altogether. In addition, the increase in percent bare ground coverage as a result of the decrease in gray leaf spot development and enhanced physiological growth response to Si may be of interest to the sod producer. A faster establishment of the grass should result in reduced expense for weed control and shorter harvest intervals.

\section{ACKNOWLEDGMENTS}

We thank King Ranch and Woerner Turf Farms for their cooperation and management of the field sites; and F. Drummond, B. Pernezny, and F. Rodrigues for their assistance in the field.

\section{LITERATURE CITED}

1. Arnon, D. I., and Stout, P. R. 1939. The essentiality of certain elements in minute quantity for plants with special reference to copper. Plant Physiol. 14:371-375.

2. Atilano, R. A., and Busey, P. 1983. Susceptibility of St. Augustinegrass germplasm to Pyricularia grisea. Plant Dis. 67:782-783.

3. Belanger, R. R., Bowen, P. A., Ehret, D. L., and Menzies, J. G. 1995. Soluble silicon: its role in crop and disease management of greenhouse crops. Plant Dis. 79:329-336.

4. Colbaugh, P. F. 1991. Efficacy of fungicides for controlling gray leaf spot on St. Augustinegrass. Tex. Agric. Exp. Stn. PR-4902:67-68.

5. Datnoff, L. E., Deren, C. W., and Snyder, G. H. 1997. Silicon fertilization for disease management of rice in Florida. Crop Prot. 16:525531.

6. Datnoff, L. E., and Nagata, R. T. 1999. Influence of silicon on grey leaf spot development in St. Augustinegrass. (Abstr.) Phytopathology 89:S19.

7. Datnoff, L. E., Snyder, G. H., and Korndorfer, G. H. 2001. Silicon in Agriculture. Elsevier, Amsterdam.

8. Elliot, C. L., and Snyder, G. H. 1991. Autoclave-induced digestion for the colorimetric determination of silicon in rice straw. J. Agric. Food Chem. 39:1118-1119.

9. Epstein, E. 1994. The anomaly of silicon in plant biology. Proc. Natl. Acad. Sci. 91:1117.

10. Freeman, T. E. 1962. Gray leaf spot preys on St. Augustinegrass. Fla. Agric. Exp. State Res. Rep. 7(2):8-9.

11. Freeman, T. E. 1971. Diseases of warm season turfgrasses. Pages 31-41 in: Proc. Scotts Turfgrass Res. Conf. Vol. 2. Turfgrass Diseases. O. M. Scott \& Sons, Marysville, OH.

12. Gussak, E., Petrovic, A. M., and Nelson, E. B. 1999. Silicon impact on the growth and disease severity of creeping bentgrass. (Abstr.) Crop Sci. C-5:136.

13. Haydu, J. J., Satterthwaite, L. N., and Cisar, J. L. 1998. An economic and agronomic profile of Florida's sod industry in 1996. Econ. Inf. Rep. EI 98-7:3-10.

14. Inanga, S., Okasaka, A., and Tanaka, S. 1995. Does silicon exist in association with organic compounds in rice plant? Soil Sci. Plant Nutr. 11:111-117.

15. Korndorfer, G. H., Snyder, G. H., Ulloa, M., Powell, G., and Datnoff, L. E. 2001 Calibration of soil and plant silicon analysis for rice 
production. J Plant Nutr 24:1071-1084.

16. Ma, J. F., and Takahashi, E. 1993. Interaction between calcium and silicon in water-cultured rice plants. Plant Soil 148:107-113.

17. Malca, I. M., and Owen, J. H. 1957. The grayleaf-spot disease of St. Augustinegrass. Plant Dis. Rep. 41:871-875.

18. Marschner, H. 1995. Pages 417-426 in: Mineral Nutrition of Higher Plants. Academic Press. San Diego, CA.

19. Saigusa, M., Onozawa, K., Watanabe, H., and Shibuya, K. 2000. Effects of porous hydrate calcium silicate on the wear resistance, insect resistance, and disease tolerance of turf grass "Miyako". Grassl. Sci. 45:416-420.
20. Savant N. K., Korndorfer, G. H., Datnoff, L. E., and Snyder, G. H. 1999. Silicon nutrition and sugarcane production: a review. J. Plant Nutr. 22(12): 1853-1903.

21. Savant N. K., Snyder, G. H., and Datnoff L. E. 1997. Silicon management and sustainable rice production. Adv. Agron. 58:151-199.

22. Seebold, K. W. 1998. The influence of silicon fertilization on the development and control of blast, caused by Magnaporthe grisea (Hebert) Barr, in upland rice. Ph.D. diss. University of Florida, Gainesville.

23. Simone, G., and Elliott, M. 1998. Disease control in turf: common turf diseases. Fact Sheet PDMG-V2-14. Fla. Coop. Ext. Serv.
IFAS, University of Florida.

24. Snyder, G. H. 1991. Development of a silicon test for Histosol-grown rice. Pages 29-39 in: Belle Glade EREC Res. Rep. EV-1991-2. University of Florida, Belle Glade.

25. Van der Plank, J. E. 1963. Plant Diseases: Epidemics and Control. Academic Press, New York.

26. Vincelli, P. 2000. Fungicidal control of gray leaf spot. Univ. Ky. Coll. Agric. Coop. Ext. Serv. Ky. Pest News \#880.

27. Wolf, B. 1982. A comprehensive system of leaf analyses and its use for diagnosing crop nutrient status. Commun. Soil Sci. Plant Anal. 13(12):1035-1059. 